\title{
Gastric secretion and fermentation in the suckling pig
}

\author{
By P. D. CRANWELL*, D. E. NOAKES† AND K. J. HILL \\ Unilever Research Laboratory, Colworth House, \\ Sharnbrook, Bedford
}

(Received 29 September 1975 - Accepted 5 Fanuary 1976)

\begin{abstract}
I. The contribution to acidification of the stomach contents of pigs by hydrochloric acid secretion or by lactic acid produced by fermentation was studied in fifteen suckling pigs from six litters born and reared either in a 'conventional' environment or in an isolated 'clean' environment. Sequential samples of stomach contents obtained during periods of up to $24 \mathrm{~h}$ were analysed for their chloride and lactic acid contents, $\mathrm{pH}$ and total titratable acidity. These values gave a measure of organic and inorganic acids respectively.

2. Six pigs from two litters born and reared in a 'clean' environment had acid secretion in the stomach at $2 \mathbf{d}$ of age, and the concentrations of lactic acid in stomach contents remained low (0-40 $\mathrm{mmol} / \mathrm{l}$ ) throughout the suckling period.

3. Eight pigs from three litters born and reared in a 'conventional' environment, and a ninth pig born in this environment but moved to the 'clean' environment at $24 \mathrm{~h}$ of age, had lactic acid in concentrations of up to $250 \mathrm{mmol} / \mathrm{l}$ in stomach contents within the rst week of life. The pattern of lactic acid production (and hence the acidity of stomach contents) was governed by the frequency of suckling.

4. Both between- and within-litter variation in the age of onset of $\mathrm{HCl}$ secretion was evident in the group reared in a 'conventional' environment, and when $\mathrm{HCl}$ secretion did occur it was usually accompanied by a reduction in lactic acid production.

5. It is concluded: ( $I$ ) that the environment at birth is important in determining the fermentative ability of the stomach flora; (2) that if lactic acid is produced in large amounts in the stomach, it may partly or completely inhibit acidification by $\mathbf{H C l}$.
\end{abstract}

In pigs of 6 weeks of age and older the capacity of the stomach to secrete both acid and proteolytic enzyme has been clearly established (Noakes, Cranwell \& Hill, 1968). Whether hydrochloric acid secretion in the stomach occurs in the suckling pig is less clear. Kvasnitskii \& Bakeeva (1943), Kvasnitskii (195I) and Walker (1959) did not detect free $\mathrm{HCl}$ in the stomach contents of suckling pigs, and the $\mathrm{pH}$ values of 3.4-5.2 reported by Catron, Baker \& Hartman (1957) and Hartman, Hays, Baker, Neagle \& Catron ( $196 \mathrm{r}$ ) led them to conclude that $\mathrm{HCl}$ is not secreted in significant amounts before weaning. Cunningham \& Brisson (1957), however, found that free acid was present during the Ist week of life, and $\mathrm{pH}$ values as low as $2 \cdot 0$ were found in pigs at $3 \mathrm{~d}$ of age by Smith \& Jones (I963). Starovoitov (I957) and Maner, Pond, Loosli \& Lowry (1962) also found, in animals with gastric pouches and fistulas, that $\mathrm{HCl}$ secretion had begun by $2-4$ weeks of age.

The failure by some workers to detect free $\mathrm{HCl}$ in stomach contents may have been due to the buffering properties of milk, saliva, gastric mucus, and regurgitated bile and pancreatic juice, and not necessarily to the absence of acid secretion. Conversely, evidence of marked acidity, based only on $\mathrm{pH}$ measurements, may have

* Present address: School of Agriculture, La Trobe University, Bundoora, Victoria 3083, Australia.

$\dagger$ Present address: Department of Surgery and Obstetrics, The Royal Veterinary College, Hawkshead House, Hawkshead Lane, North Mimms, Hatfield, Herts. 
reflected the presence of organic acids produced by gastric fermentation (Friend, Cunningham \& Nicholson, I963) rather than the result of $\mathrm{HCl}$ secretion. It is also possible that the conflicting findings of different studies may reflect true variations in the maturity of individual pigs within and between litters.

The aims of the experiments reported here were to study more fully the onset of $\mathrm{HCl}$ secretion in the baby pig, to study the secretory and fermentative patterns in the stomach, and to determine whether there is a relationship between acid secretion and fermentation in the stomach. A preliminary report of these experiments has been made (Cranwell, Noakes \& Hill, 1968 ).

\section{EXPERIMENTAL}

\section{Pigs and their treatment}

Expt I

Animals and housing. Details of the pigs used in this experiment (litters I F-6F inclusive) are given in Table $\mathrm{I}$. The two environments in which pigs were born and reared were: (I) ark: the rearing ark was in proximity to similar arks. The creep area was provided with an infrared lamp as an additional source of heat, and sawdust was used for bedding. This environment was termed 'conventional'; (2) metabolism house: the sow and litter were housed in two adjacent pens connected by a small opening in the dividing wall; one pen was used as a creep area, and was provided with an infrared lamp; sawdust was used for bedding. The room containing the pens was rarely used for rearing young pigs, and was free from direct or indirect contact with other pigs. Ventilation and temperature were controlled by an airconditioning system. Air temperature was maintained between $I 8$ and $21^{\circ}$. This environment was termed 'clean'.

Anaesthesia and surgical preparation. Anaesthesia was induced with cyclopropaneoxygen administered by face-mask (Hall's mask, small dog-size; British Oxygen Co., London) and maintained with cyclopropane- $\mathrm{O}_{2}$ after intranasal intubation (Magill tube sizes 2.5-3.0; Arnolds Veterinary Products Ltd, Reading). Stomach contents were aspirated, using a stomach tube, after the pig was anaesthetized and before surgery.

Gastric fistulas were prepared in fifteen pigs, selected at random without reference to sex or body-weight from forty pigs in six litters. Fistulas were made in the fundic gland of the greater curvature, with Perspex cannulas ( $9.0 \mathrm{~mm}$ i.d., $12.5 \mathrm{~mm}$ o.d.). The cannulas were exteriorized through the abdominal wall, $25^{-5} \mathrm{~mm}$ to the right of the mid-line. Before exteriorization a $25 \mathrm{~mm}$ o.d. Perspex flange was screwed onto the shaft of the cannula, and placed between the visceral and parietal peritoneum to ensure firm anchorage. The lumen of the cannula was occluded with a Perspex plunger held in place by a 'screw-on' Perspex cap (Fig. r).

Surgery was completed within $6 \mathrm{~h}$ of birth and the pigs were returned to the sow after they had recovered from the anaesthetic.

Sampling of stomach contents. Samples (5-10 g) of stomach contents were collected from the fistulated pigs at known times after suckling. The pigs remained with 
Table I. Details of suckling pigs used in Expt $\mathrm{I}$

\begin{tabular}{|c|c|c|c|c|c|c|c|c|}
\hline \multirow[b]{3}{*}{ Litter } & \multirow[b]{3}{*}{ Breed } & \multirow[b]{3}{*}{ Date of birth } & \multirow{3}{*}{$\begin{array}{l}\text { Litter } \\
\text { size }\end{array}$} & \multirow{3}{*}{$\begin{array}{l}\text { Experimental } \\
\text { pig no. }\end{array}$} & \multirow{2}{*}{\multicolumn{2}{|c|}{ Environment* }} & \multicolumn{2}{|c|}{ Age (d) } \\
\hline & & & & & & & Creep feed & \\
\hline & & & & & Born & Reared & offered & Weaned \\
\hline IF & LW & Io Sept. 1966 & 6 & I & A & MH & 12 & 19 \\
\hline $2 \mathrm{~F}$ & $\mathrm{LW}_{0}^{*} \times \mathrm{We}$ 우 & I8 July 1966 & 4 & 2,3 & MH & MH & 15 & 42 \\
\hline $3 F$ & LWơ $\times$ We & if Feb. 1967 & 10 & $4-7$ & MH & MH & II & 52 \\
\hline $4 \mathrm{~F}$ & $\mathrm{~W}_{\delta}^{\star}(\mathrm{L} \times \mathrm{LW})$ 우 & 20 June 1967 & 5 & 8,9 & A & A & Io & 27 \\
\hline${ }_{5} \mathrm{~F}$ & W' $(\mathrm{L} \times \mathrm{LW})$ 우 & Io Nov. I967 & 8 & Io, II & A & A & - & $12 \dagger$ \\
\hline $6 \mathrm{~F}$ & LWơ $\times$ Wé & 23 May 1968 & 7 & $13-16$ & A & A & 12 & 33 \\
\hline
\end{tabular}

LW, Large White; We, Wessex; L, Landrace; W, Welsh; A, ark (termed 'conventional' environment); $\mathrm{MH}$, metabolism house (termed 'clean' environment).

* For details, see p. 72.

+ Experiment ended on 22 Nov. 1967 , owing to precautions against foot and mouth disease.

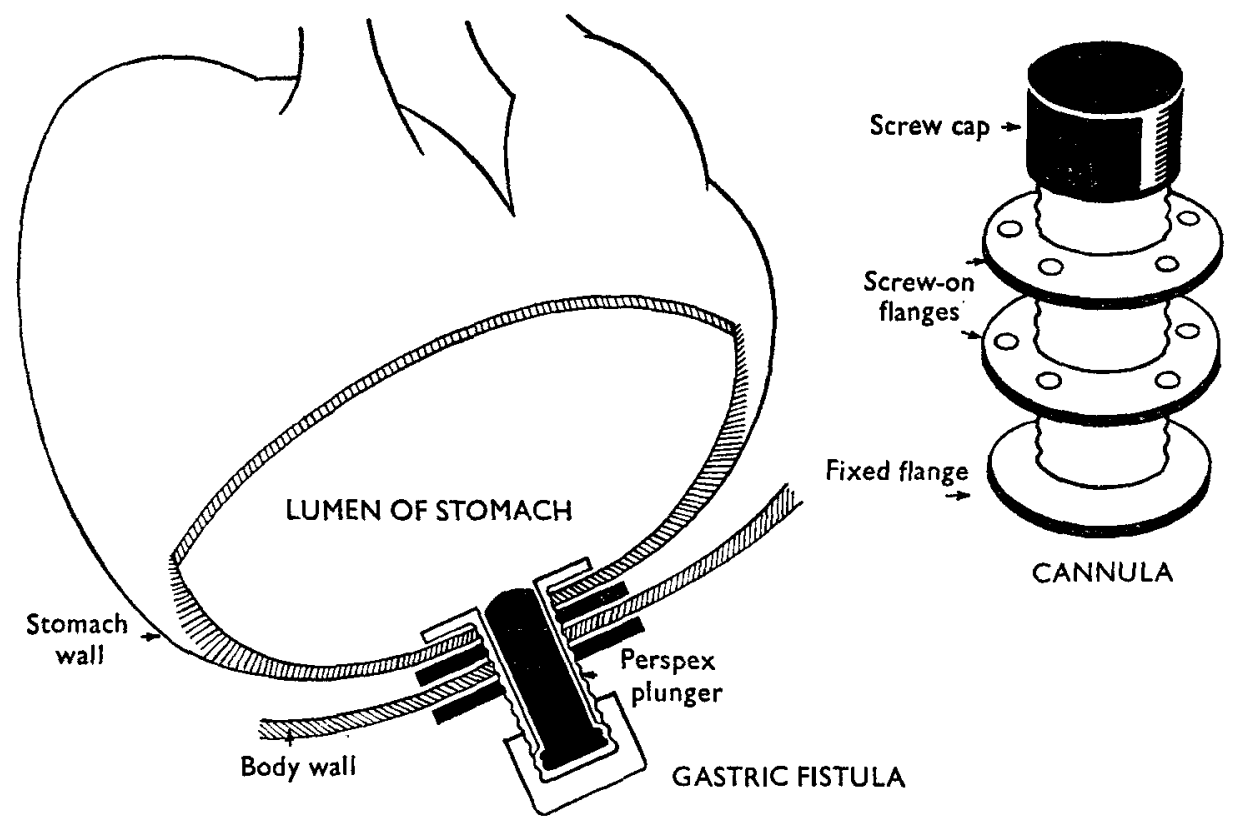

Fig. I. Expt I. Diagram of the Perspex cannula, and of its position in the stomach of the pig to form a gastric fistula.

their dams and litter-mates, and were only removed for short periods $(2-3 \mathrm{~min})$ during experiments, for sampling purposes. Except where indicated, interference with the normal suckling pattern was minimal.

\section{Expt 2}

The buffering capacity of fresh sow's milk was determined by potentiometric titration with $0.1 \mathrm{M}-\mathrm{HCl}, 0.2 \mathrm{I} \mathrm{M}$-lactic acid or pure gastric juice $(\mathrm{pH} \mathrm{r} \cdot 15$, obtained from a 12-week-old pig with a gastric pouch). The milk was obtained from a Wessex sow by hand-milking after $0.5 \mathrm{ml}$ posterior pituitary extract (Io oxytocic units/ml; 
Parke, Davis and Co., Hounslow), diluted with $0.5 \mathrm{ml}$ physiological saline $(9 \mathrm{~g}$ sodium chloride/1), was injected into an ear vein.

\section{Analytical procedures}

$p H$. $\mathrm{pH}$ of the stomach contents was determined immediately after sampling, with a direct-reading $\mathrm{pH}$ meter (Electronic Industries Ltd, Richmond, Surrey) and glass electrode.

Before further analyses each sample was thoroughly mixed and divided into subsamples.

Dry matter. Weighed samples were dried for $24 \mathrm{~h}$ in aluminium-foil dishes at 100-105. This procedure was found to give constant dry weights.

Lactic acid. Total lactic acid was determined chemically (Barker \& Summerson, 1941) and L-lactic acid by an enzymic method (Hohorst, 1965), after dilution and precipitation of protein with dilute perchloric acid $(35 \mathrm{~g} / \mathrm{l})$. Lactic acid concentration was calculated in $\mathrm{mmol} / \mathrm{I}$ undiluted stomach contents.

Chloride concentration. Samples were diluted with a known volume of deionized water, mixed, centrifuged and filtered. Chloride concentration in the filtrate was measured with a Chloride Meter (Evans Electroselenium Ltd, Halstead, Essex), and calculated in $\mathrm{mmol} / \mathrm{l}$ undiluted stomach contents.

Total acidity. Total acidity was measured by potentiometric titration, after dilution and filtration (as described previously) with $0.0 \mathrm{I} \mathrm{M-NaOH}$ to $\mathrm{pH} 9.6$ under carbon dioxide-free conditions, and the results calculated in $\mathrm{mmol} / \mathrm{l}$ undiluted stomach contents.

Volatile fatty acids $(V F A)$. Samples for VFA analysis were diluted with deionized water and deproteinized by the method described by Erwin, Marco \& Emery (196I)

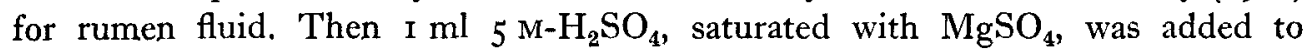
$5 \mathrm{ml}$ supernatant fraction and steam-distilled in a Markham still. The first $100 \mathrm{ml}$ of distillate were neutralized with I $\mathrm{M}-\mathrm{KOH}$, reduced in volume by heating on a hotplate, quantitatively transferred to a Durham tube containing three or four glass beads, and dried in a forced convection oven at $100^{\circ}$. The tubes were sealed with Parafilm (A. Gallenkamp \& Co. Ltd, London $\mathrm{EC}_{2}$ ), and stored at room temperature until analysed.

Total and individual VFA concentrations were determined by gas-liquid chromatography using a laboratory-built gas-liquid chromatograph fitted with a hydrogen flame-ionization detector (FID). The columns were $2 \mathrm{~m}$ long and $4 \mathrm{~mm}$ i.d., packed with neopentyl glycol adipate-orthophosphoric acid-celite (60-72 mesh) (20:2:78, by wt) (W. G. Pye \& Co., Cambridge) as the stationary phase. Operating conditions were: oven $130^{\circ}$, FID and column inlet $150^{\circ}, \mathrm{H}_{2}$ and nitrogen $50 \mathrm{ml} / \mathrm{min}$. The dried samples were taken up in $100-500 \mu \mathrm{l}$ orthophosphoric acid $(20 \mathrm{~g} / 1)$ which contained $2 \mu \mathrm{g}$ isovaleric acid $/ \mathrm{ml}$ as internal standard, and $2 \mu \mathrm{I}$ of the solution was injected ro $\mathrm{mm}$ into the column packing using a 10 $\mu$ l syringe (Hamilton $70 \mathrm{I}-\mathrm{NCH}$; Clarke Hamilton Manufacturing AG, Switzerland). The concentrations of individual VFA were calculated from the response ratios determined by Ackman \& Sipos (1964). 


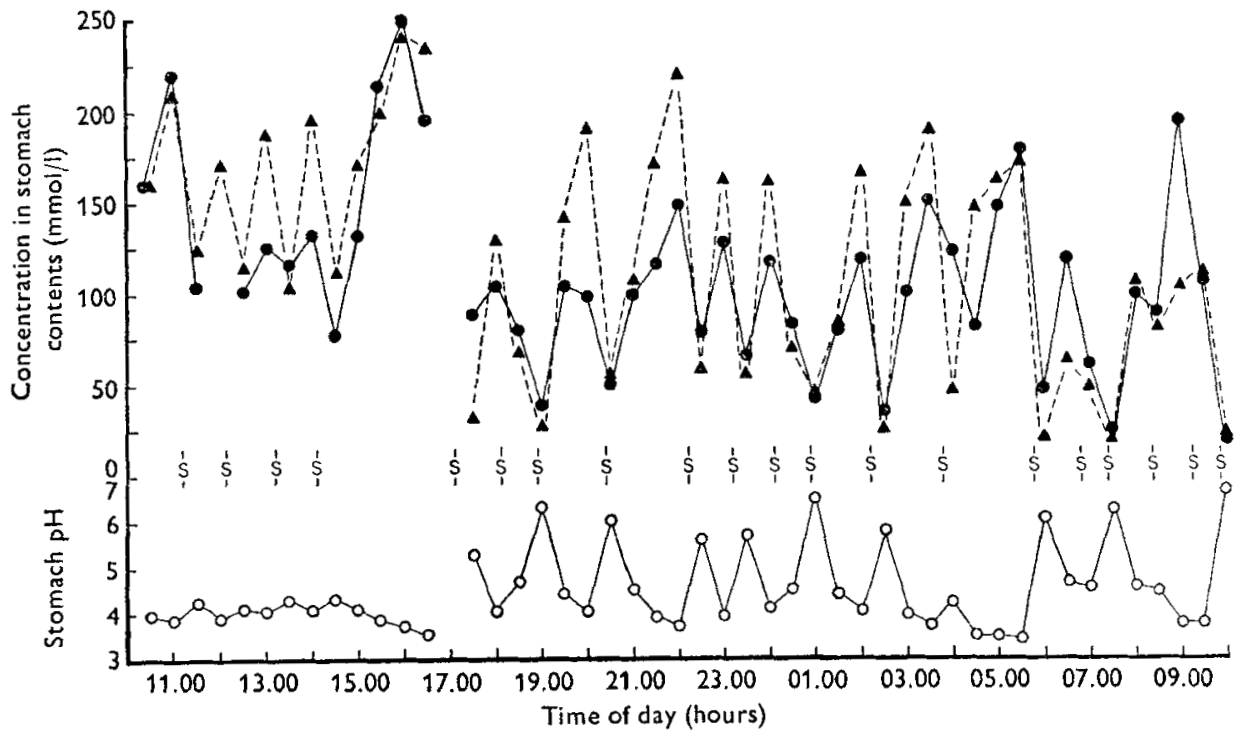

Fig. 2. Expt I. Analyses of stomach contents obtained from pig no. I (litter I F, born in 'conventional'; reared in 'clean' environment (for details, see p. 72)), 4-5 d of age, at $30 \mathrm{~min}$ intervals throughout a $24 \mathrm{~h}$ period. (O), Total acidity; (A), lactic acid; (O), $\mathrm{pH}$; (S), occurrence of suckling.

\section{RESULTS}

\section{Expt I}

All pigs made satisfactory recoveries after surgery, and had resumed normal suckling activity by the time they were $12 \mathrm{~h}$ old. In the first three litters sampling did not begin until the pigs were $48 \mathrm{~h}$ old, but it was found later that recovery was not hindered if a few samples were taken within this period. Apart from the pigs in litter $4 \mathrm{~F}$, which had diarrhoea during part of the experimental period, the 'operated' animals remained healthy throughout the experiment, and grew at the same rate as their 'unoperated' litter-mates.

The appearance and nature of the stomach contents from pigs of similar ages and from all litters were comparable, and stomach contents collected 2-3 min after suckling appeared to consist of unchanged milk. At 5 min after suckling had ceased, soft, gelatinous clots were present, and during the subsequent $30 \mathrm{~min}$ these became granular in appearance, although still remaining soft. During the next $30 \mathrm{~min}$ the stomach contents became drier, crumbled readily and were frequently bile-stained. The appearance of the stomach contents was altered after the introduction of creep feed, and the proportion of creep mixed with clot increased with the period of time after suckling. However, the milk clot itself appeared similar to that obtained earlier in the piglets' lives. Small quantities of straw and sawdust were occasionally found in the stomach contents.

Pig no. I, litter I F (born in 'conventional'; reared in 'clean' environment after 24 of life). Samples of stomach contents were taken at $30 \mathrm{~min}$ intervals during periods of 7.5 and $24 \mathrm{~h}$, when the pig was 3 and $4-5 \mathrm{~d}$ old respectively. Further collections throughout a $24 \mathrm{~h}$ period were made at $\mathrm{II}-12 \mathrm{~h}$ of age. The results at $4-5 \mathrm{~d}$ of age 


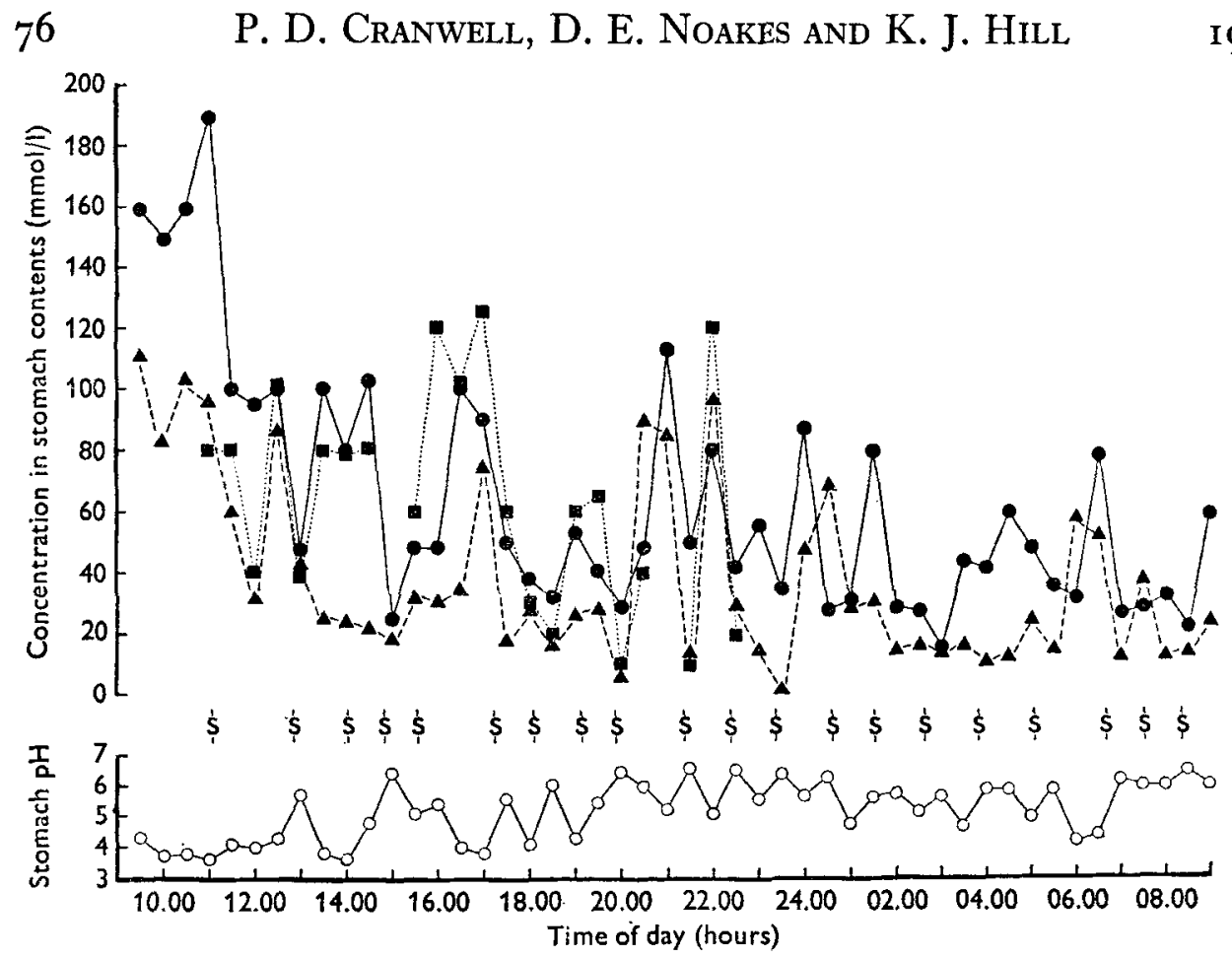

Fig. 3. Expt I. Analyses of stomach contents obtained from pig no. I (litter I $F$, born in 'conventional'; reared in 'clean' environment (for details, see p. 72)), 11-12 d of age, at $30 \mathrm{~min}$ intervals throughout a $24 \mathrm{~h}$ period. (O), Total acidity; ( $\mathbf{A})$, lactic acid; ( $\mathbf{U})$, chloride; (O), $\mathrm{pH}$; (S), occurrence of suckling.

were similar to those obtained at $3 \mathrm{~d}$ of age, and are shown in Fig. 2. The total acidity of the stomach contents paralleled the lactic acid concentration; mean values $( \pm \mathrm{SD})$ for the forty-seven samples, lactic acid I $19 \pm 64 \mathrm{mmol} / \mathrm{l}$, total acidity $108 \pm 52$ $\mathrm{mmol} / \mathrm{l}$. The pattern of lactic acid production and total acidity was related to the frequency of feeding, each addition of milk to the stomach being accompanied by a decrease in lactic acid concentration and a parallel reduction in acidity. The concentration of lactic acid found in the digesta after each meal was directly related to the period of time available for fermentative activity before the next intake of milk. Long periods between suckling, when the stomach contents were not diluted by milk, were characterized by an increase in lactic acid concentration and in acidity.

At II-12 d of age (Fig. 3) there was a similar but less well-defined relationship between the total acidity of the stomach contents and feeding frequency than that found at $3^{-5} \mathrm{~d}$, although the concentrations $(64 \pm 4 \circ(\mathrm{SD}) \mathrm{mmol} / \mathrm{l})$ were much lower. The lactic acid concentrations $(39 \pm 30(\mathrm{sD}) \mathrm{mmol} / \mathrm{l})$ were not only much lower than the total acidity, but were, at many sampling times, unrelated. Chloride concentrations (64 \pm 35 (SD) mmol/1; twenty-two determinations) usually paralleled total acidity, indicating that the latter was largely attributable to $\mathrm{HCl}$ and not to lactic acid.

Pig nos. 2-7, litters $2 F$ and $3 F$ (born and reared in 'clean' environment). The lactic acid concentration in sequential samples obtained from the six fistulated pigs of litters $2 \mathrm{~F}$ and $3 \mathrm{~F}$ remained low, and never reached the concentrations found in 


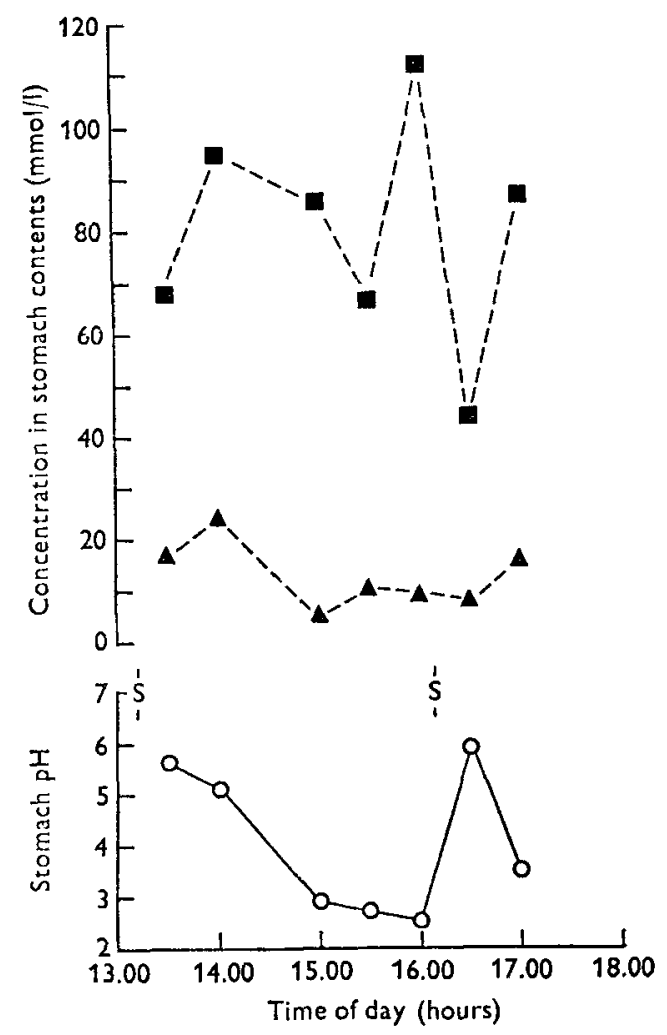

Fig. 4. Expt 1. Analyses of stomach contents obtained from pig no. 3 (litter $2 \mathrm{~F}$, born and reared in 'clean' environment (for details, see p. 72 )), $2 \mathrm{~d}$ of age, during a $4 \mathrm{~h}$ period in which the pig was not given access to the sow for $3 \mathrm{~h}$. ( $\square$ ), Chloride; ( $\Delta$ ), lactic acid; (O), $\mathrm{pH}$; (S), occurrence of suckling.

pig no. I. Total acidity was also lower, but was directly correlated with chloride content and $\mathrm{pH}$ from $2 \mathrm{~d}$ of age, indicating acid-secretory activity. The lactic acid concentration in the stomach contents did not increase between feeds (Fig. 4).

From $3 \mathrm{~d}$ of age until the pigs started eating creep feed at 2-3 weeks of age the chloride concentration in the stomach contents was higher than total acidity, and there was a definite acid-secretory pattern in relation to suckling, e.g. pig no. 6, litter $3 \mathrm{~F}$ at $\mathrm{I}_{3} \mathrm{~d}$ of age (Fig. 5). The acid-secretory response to a meal was, however, somewhat obscured by the repeated addition of fresh milk on each occasion that the pig suckled, and it was only when further access to the sow was not given that the full secretory response to a meal was obtained (Fig. 6). There was a progressive decrease in the $\mathrm{pH}$ of the stomach contents, paralleled by an increase in chloride concentration during the $4 \mathrm{~h}$ after feeding.

Low $\mathrm{pH}$ values $(1 \cdot 7-2 \cdot 9)$ were found in thirty-three samples of stomach contents from the fistulated pigs of litters $2 \mathrm{~F}$ and $3 \mathrm{~F}$ between 2 and $2 \mathrm{I} \mathrm{d}$ of age. These excluded those samples collected after the piglets were prevented from suckling by placing them in an adjacent pen.

Although creep feed was provided for the pigs of litters $2 \mathrm{~F}$ and $3 \mathrm{~F}$ from $\mathrm{II}^{-1} \mathrm{I}_{5} \mathrm{~d}$ 


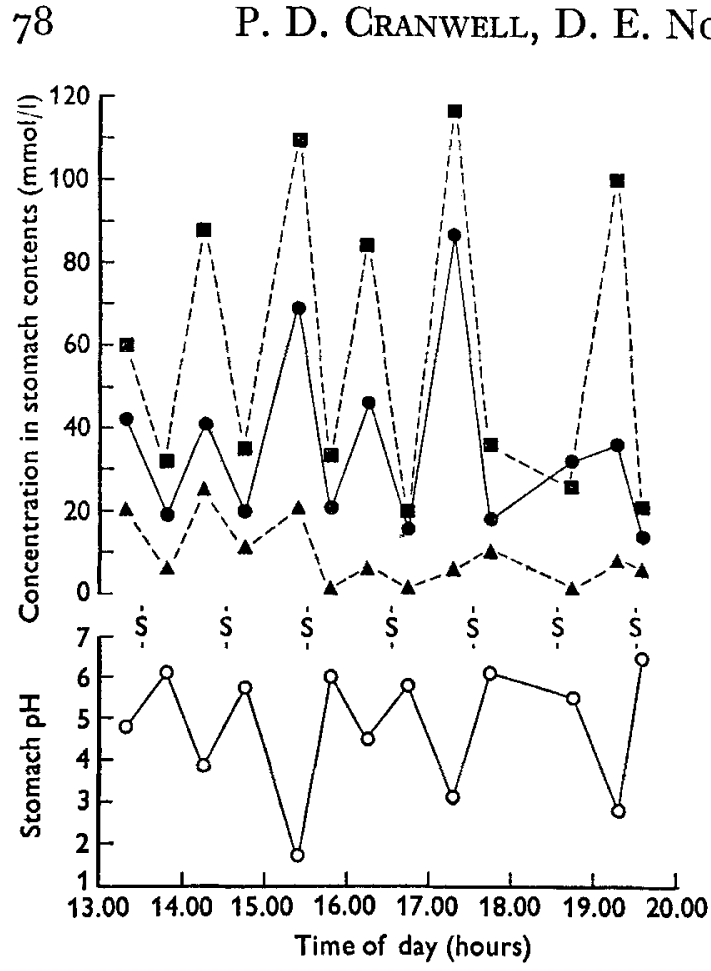

Fig. 5

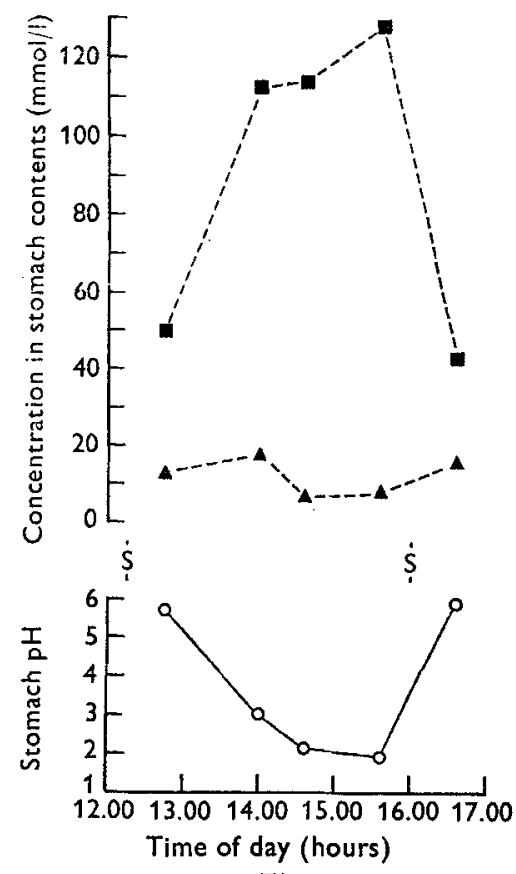

Fig. 6

Fig. 5. Expt I. Analyses of stomach contents obtained from pig no. 6 (litter $3 \mathrm{~F}$, born and reared in 'clean' environment (for details, see p. 72)), $13 \mathrm{~d}$ of age, at 30 min intervals throughout a 7 h period. ( $\mathbf{O})$, Chloride; (O), total acidity; $(\boldsymbol{\Delta})$, lactic acid; (O), $\mathrm{pH} ;(\mathrm{S})$, occurrence of suckling.

Fig. 6. Expt 1. Analyses of stomach contents obtained from pig no. 2 (litter $2 \mathrm{~F}$, born and reared in 'clean' environment (for details, see p. 72)), is d of age, during a $5 \mathrm{~h}$ period in which the pig was not given access to the sow for $4 \mathrm{~h}$. (D), Chloride; $(\Delta)$, lactic acid; (O), $\mathrm{pH}$; (S), occurrence of suckling.

of age, very little was consumed until they were about ${ }_{17-1} 8 \mathrm{~d}$ old. At this age they suddenly began to eat appreciable amounts at regular intervals, which led to comparatively uniform acidity of the stomach contents (Fig. 7). Lactic acid concentration remained low. The $\mathrm{pH}$ was higher than when the pigs were receiving milk only, and the chloride concentrations were comparatively high, reflecting the higher chloride content $(200 \mathrm{mmol} / \mathrm{kg})$ of creep feed compared with that $(34 \mathrm{mmol} / \mathrm{kg}$; Perrin, 1955) for sow's milk. Subsequent samples had uniform acidity of $60-80 \mathrm{mmol} / \mathrm{l}, \mathrm{pH}$ approximately 4.0 , and contained negligible amounts of lactic acid.

Pig nos. 8 and 9, litter $4 F$ (born and reared in 'conventional' environment). In the first $2 \mathrm{~d}$ of life, lactic acid concentration in the stomach contents from both pigs was low (Table 2). There was some evidence that $\mathrm{HCl}$ secretion had occurred in pig no. 8 between 2 and $3 \mathrm{~d}$ of age since two samples had very low $\mathrm{pH}$ values $(2.9$ and $2 \cdot 6$ ) and high chloride concentrations ( 97 and $86 \mathrm{mmol} / \mathrm{l}$ respectively). Between 3 and $17 \mathrm{~d}$ of age the results from both pigs were similar to those of pig no. I which had been born in a 'conventional' environment. Both pigs had high concentrations of lactic acid in their stomach contents, and total acidity was always higher than the 


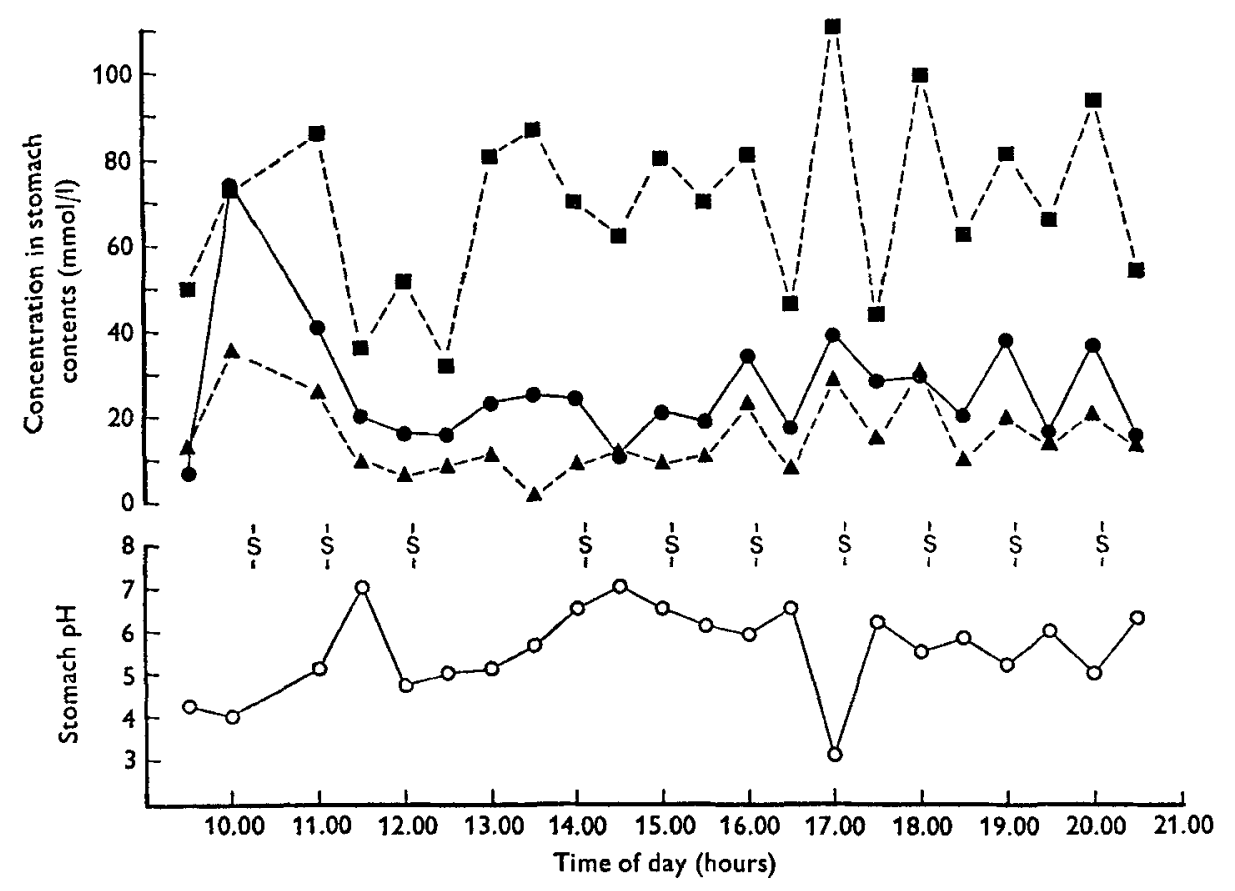

Fig. 7. Expt 1. Analyses of stomach contents obtained from pig no. 3 (litter 2 F, born and reared in 'clean' environment (for details, see p. 72)), $20 \mathrm{~d}$ of age, at 30 min intervals throughout a $12 \mathrm{~h}$ period. ( $\mathbf{(})$, Chloride; (O), total acidity; ( $\mathbf{\Delta})$, lactic acid; $(\mathrm{O}), \mathrm{pH}$; (S), occurrence of suckling.

chloride concentration. Acid secretion in the stomach was again apparent in pig no. 8 from 20 to $24 \mathrm{~d}$ of age. The total acidity and lactic acid concentration in the stomach contents from this animal were significantly lower than those found in pig no. 9 (Table 2), whereas the chloride concentration was significantly higher $(P<0.005$; $t$ test (Snedecor \& Cochran, I967)).

Pig nos. 10 and I I, litter $5 F$ (born and reared in 'conventional' environment). Although both pigs from litter $5 \mathrm{~F}$ had high concentrations of lactic acid in their stomach contents there was variation in the age at which the greatest concentrations were found. Pig no. Io, for example, secreted $\mathrm{HCl}$ during the first $5 \mathrm{~d}$ of life, and only minimal concentrations of lactic acid were found in stomach contents during this period. From $6 \mathrm{~d}$ of age lactic acid concentration increased markedly and remained high until the experiment was ended at $12 \mathrm{~d}$, owing to precautions against foot and mouth disease (Table 3 ; Fig. 8). The lactic acid concentration in stomach contents from pig no. II, however, was high throughout the experimental period, and there was no evidence of $\mathrm{HCl}$ secretion during the first $6 \mathrm{~d}$ of life (Table 3; Fig. 8). In contrast to the previous results the inverse relationship between chloride and lactic acid concentrations was not consistently evident, since there were days during the experimental period when samples of stomach contents were found to contain high concentrations of both chloride and lactic acid.

Pig nos. 13-16, litter $6 F$ (born and reared in 'conventional' environment). The 


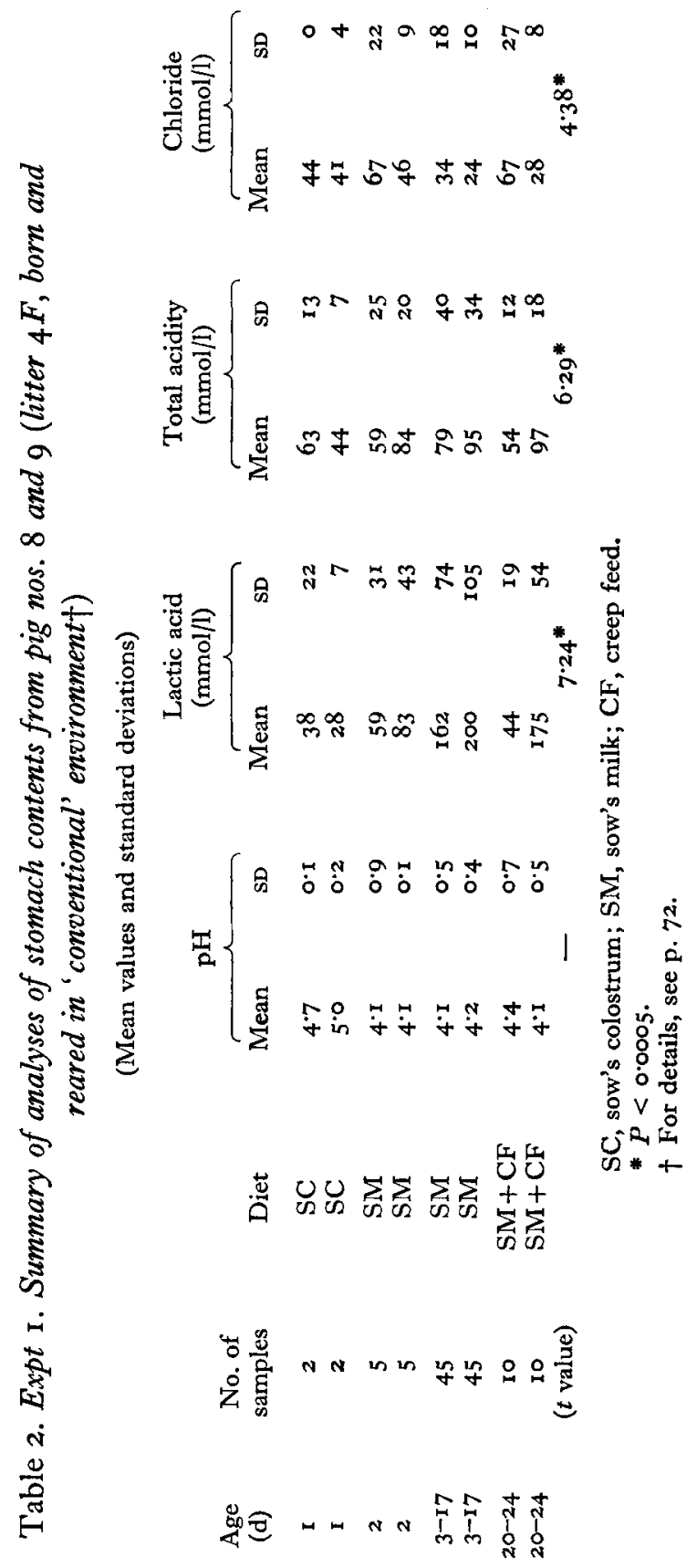

$\ddot{\theta} \infty a \infty a \infty a \infty a$ 
Table 3. Expt I. Summary of analyses of stomach contents from pig nos. Io and I I (litter ${ }_{5} F$, born and reared in 'conventional' environment*)

(Mean values and standard deviations)

\begin{tabular}{|c|c|c|c|c|c|c|c|c|}
\hline \multirow{2}{*}{$\begin{array}{l}\text { Pig } \\
\text { no. }\end{array}$} & \multirow{2}{*}{$\begin{array}{l}\text { Age } \\
\text { (d) }\end{array}$} & \multirow{2}{*}{$\begin{array}{l}\text { No. of } \\
\text { samples }\end{array}$} & \multicolumn{2}{|c|}{$\mathrm{pH}$} & \multicolumn{2}{|c|}{$\begin{array}{l}\text { Lactic acid } \\
(\mathrm{mmol} / \mathrm{l})\end{array}$} & \multicolumn{2}{|c|}{$\begin{array}{l}\text { Chloride } \\
(\mathrm{mmol} / \mathrm{l})\end{array}$} \\
\hline & & & Mean & so & Mean & SD & Mean & SD \\
\hline $\begin{array}{l}\text { IO } \\
\text { II }\end{array}$ & 3 & $\begin{array}{l}6 \\
6\end{array}$ & $\begin{array}{l}4 \cdot 6 \\
3 \cdot 8\end{array}$ & $\begin{array}{l}0.9 \\
0.3\end{array}$ & $\begin{array}{l}21 \\
95\end{array}$ & $\begin{array}{r}9 \\
34\end{array}$ & $\begin{array}{l}69 \\
58\end{array}$ & $\begin{array}{l}22 \\
20\end{array}$ \\
\hline $\begin{array}{l}\text { IO } \\
\text { II }\end{array}$ & 4 & $\begin{array}{l}6 \\
7\end{array}$ & $\begin{array}{l}4 \cdot 8 \\
4 \cdot 3\end{array}$ & $\begin{array}{l}0.7 \\
0.2\end{array}$ & $\begin{array}{r}13 \\
102\end{array}$ & $\begin{array}{r}6 \\
34\end{array}$ & $\begin{array}{l}72 \\
49\end{array}$ & $\begin{array}{r}15 \\
7\end{array}$ \\
\hline $\begin{array}{l}\text { IO } \\
\text { II }\end{array}$ & 5 & $\begin{array}{l}7 \\
8\end{array}$ & $\begin{array}{l}5 \cdot 0 \\
3^{\cdot} \cdot 6\end{array}$ & $\begin{array}{l}0.7 \\
0.1\end{array}$ & $\begin{array}{r}13 \\
183\end{array}$ & $\begin{array}{r}7 \\
39\end{array}$ & $\begin{array}{l}74 \\
44\end{array}$ & $\begin{array}{r}23 \\
5\end{array}$ \\
\hline $\begin{array}{l}\text { 10 } \\
\text { II }\end{array}$ & 6 & $\begin{array}{l}7 \\
7\end{array}$ & $\begin{array}{l}5 \cdot 2 \\
4 \cdot 5\end{array}$ & $\begin{array}{l}0.2 \\
0.5\end{array}$ & $\begin{array}{l}67 \\
88\end{array}$ & $\begin{array}{l}22 \\
46\end{array}$ & $\begin{array}{l}36 \\
48\end{array}$ & $\begin{array}{r}9 \\
10\end{array}$ \\
\hline $\begin{array}{l}10 \\
\text { II }\end{array}$ & 7 & $\begin{array}{l}5 \\
4\end{array}$ & $\begin{array}{l}5 \cdot 2 \\
4 \cdot 9\end{array}$ & $\begin{array}{l}0.3 \\
0.9\end{array}$ & $\begin{array}{l}70 \\
91\end{array}$ & $\begin{array}{l}36 \\
59\end{array}$ & $\frac{78}{-}+$ & 15 \\
\hline $\begin{array}{l}10 \\
11\end{array}$ & Io & $\begin{array}{l}4 \\
6\end{array}$ & $\begin{array}{l}4.7 \\
4.1\end{array}$ & $\begin{array}{l}1 \cdot 1 \\
0.4\end{array}$ & $\begin{array}{l}120 \\
113\end{array}$ & $\begin{array}{l}99 \\
46\end{array}$ & ${ }_{118}^{\dagger}$ & $\frac{-1}{16}$ \\
\hline II & I I & 6 & 4.4 & 0.4 & ${ }_{135}$ & 42 & 66 & 23 \\
\hline
\end{tabular}

* For details, see p. 72 .

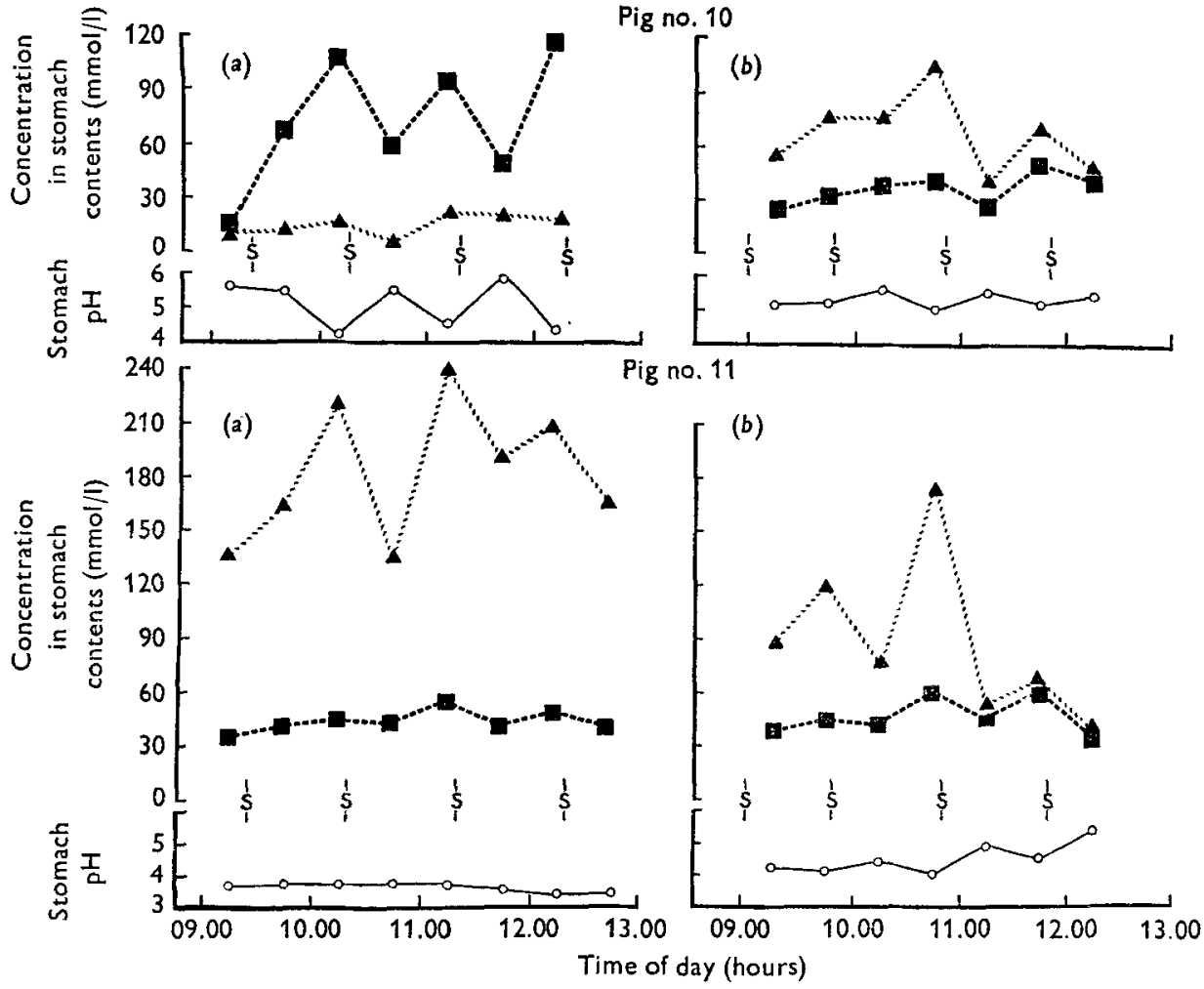

Fig. 8. Expt I. Analyses of stomach contents obtained from pig nos. Io and Ir (litter $5 \mathrm{~F}$, born and reared in 'conventional' environment (for details, see p. 72)), at 30 min intervals during $4 \mathrm{~h}$ periods on two consecutive days: $(a)$ at $5 \mathrm{~d}$ of age, $(b)$ at $6 \mathrm{~d}$ of age. $(\mathbb{D})$, Chloride; (A), lactic acid; (O), $\mathrm{pH}$; (S), occurrence of suckling. 

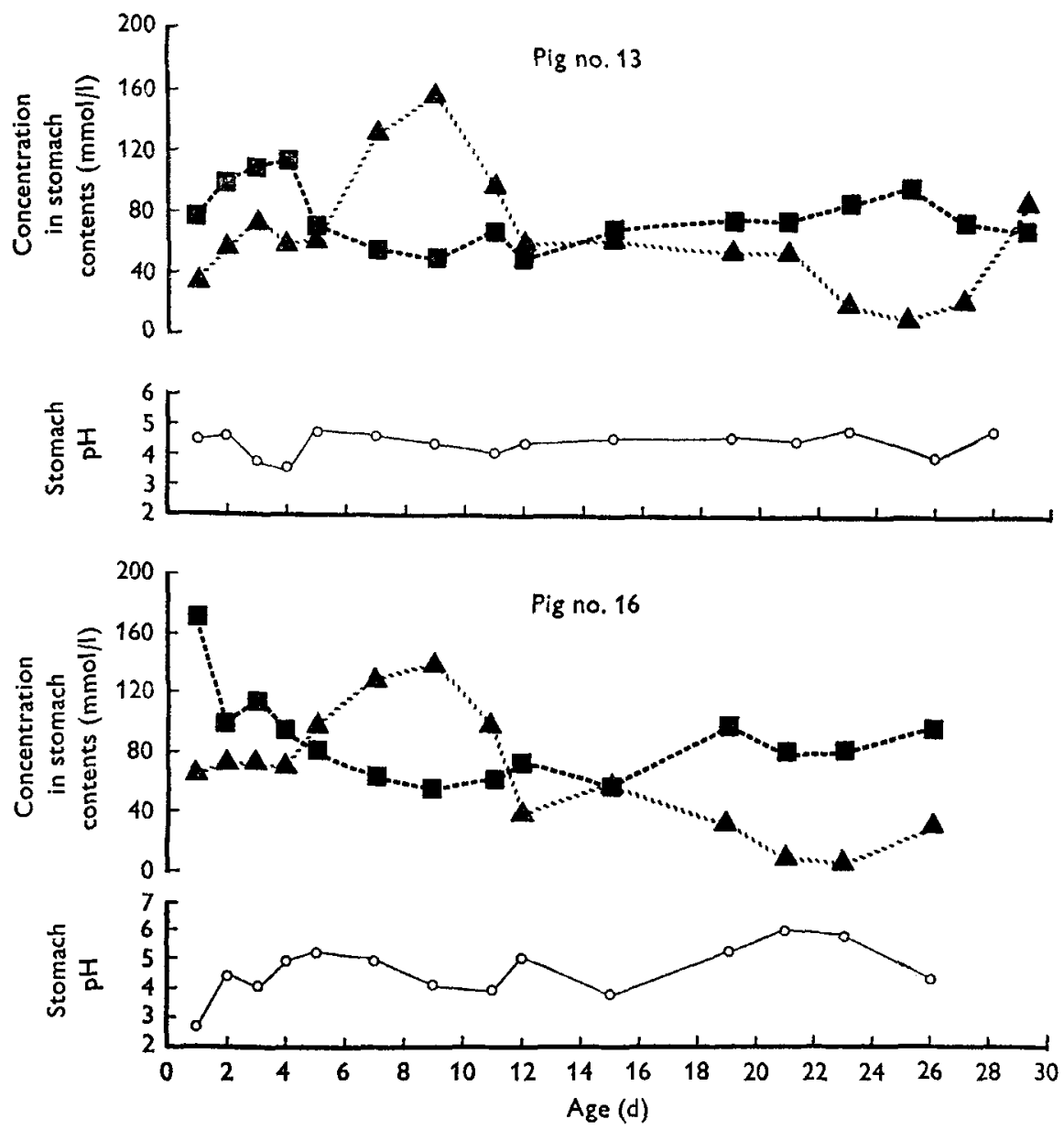

Fig. 9. Expt I. Analyses of stomach contents obtained from pig nos. 13 and 16 (litter $6 \mathrm{~F}$, born and reared in 'conventional' environment (for details, see p. 72)) during the first

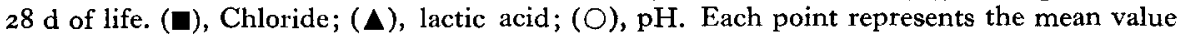
for at least six samples/d; the same number of samples were obtained at 15 and $45 \mathrm{~min}$ after suckling.

lactic acid concentration in stomach contents of the pigs of litter $6 \mathrm{~F}$ was low, and was lower than that for chloride for the first $4 \mathrm{~d}$ of life; also $\mathrm{pH}$ values as low as 2.7 were found, indicating that acid secretion in the stomach occurred in all four pigs during this time. After $5 \mathrm{~d}$ of age there was a marked increase in lactic acid concentration and a parallel decrease in chloride concentration, which persisted for $6 \mathrm{~d}$. During the next $15 \mathrm{~d}$ there was a gradual decrease in lactic acid concentration and a corresponding increase in chloride concentration. The results for pig nos. 13 and 16 are shown in Fig. 9, and are representative of the results obtained for all four pigs.

Organic acid. Lactic acid comprised $80-100 \%$ and VFA $0-20 \%$ of the total organic acid fraction in all samples of stomach contents from the fistulated pigs. Acetic acid formed the greater proportion of the VFA, and propionic acid, although 


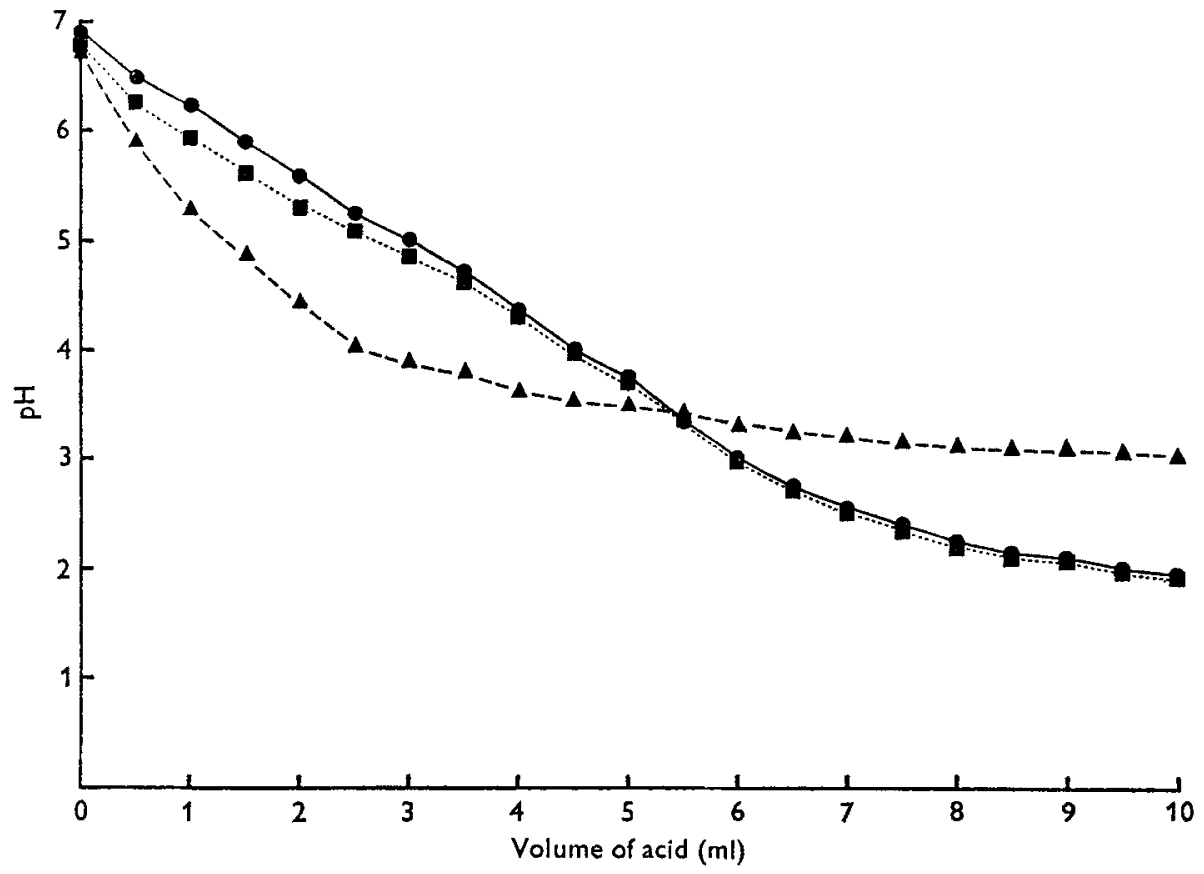

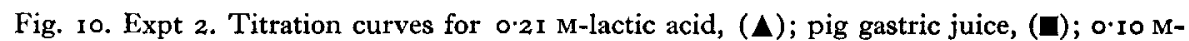
hydrochloric acid, $(\odot)$; with fresh sow's milk $(5 \mathrm{ml})$. For details of experimental procedures, see pp. 73-4.

usually present in stomach contents, comprised $<\mathrm{r} \%$ of the total organic acids. Traces of butyric acid were occasionally found.

The proportions in which individual isomers of lactic acid occurred in stomach contents were determined in twenty samples for two pigs of litter ${ }_{5} \mathrm{~F}$. L-lactic acid was estimated enzymically and D-lactic acid was estimated as the difference between total lactic acid and L-lactic acid. The proportion of L-lactic acid for pig no. Io was $57 \pm 10 \%$ and for pig no. II was $44 \pm 8 \%$, and the difference between the mean values was significant $(P<0.05)$.

\section{Expt 2}

The titration curves for sow's milk, a pooled sample obtained from three milkings on consecutive days, with $\mathrm{HCl}$, pig gastric juice, and lactic acid, are shown in Fig. Io. The curves for $\mathrm{HCl}$ and for pig gastric juice were very similar; both were approximately linear to $\mathrm{pH} 2 \cdot 75$. However, the curve for lactic acid decreased more rapidly initially, then remained relatively stable at about $\mathrm{pH}_{3} \cdot \mathrm{I}$. The amounts of $\mathrm{HCl}$ and lactic acid required to reduce the $\mathrm{pH}$ of $\mathrm{I} 1$ sow's milk to $\mathrm{pH} 3 \cdot 0$ were I 20 and $480 \mathrm{mmol}$ respectively.

\section{DISCUSSION}

The unequivocal finding that $\mathrm{HCl}$ secretion takes place is complicated by the fact that fermentative activity occurs in the stomach of some pigs, and lactic acid, which is appreciably ionized at $\mathrm{pH}_{3} \cdot 0$, may then accumulate in the stomach (Friend 
et al. 1963). The curves produced by titration of sow's milk with $\mathrm{HCl}$ and with lactic acid not only indicated that appreciable buffering capacity of the milk, but also indicated that lactic acid, at a concentration comparable to that found in the stomach contents of many young pigs, was as effective as gastric juice, or $\mathrm{HCl}$ of equivalent acidity, in reducing the $\mathrm{pH}$ of milk to 3.5 . Unequivocal evidence for the presence of $\mathrm{HCl}$ in stomach contents, therefore, can only be obtained if chloride and lactic acid concentrations are determined in addition to $\mathrm{pH}$ and acidity, although it is reasonable to assume that acidity in the stomach is caused by $\mathrm{HCl}$ secretion when the $\mathrm{pH}$ is less than $3^{\circ} \circ$ (James, 1957 ).

These procedures were used in the present work, and it was found that the age at which $\mathrm{HCl}$ secretion could be regularly detected varied between pigs within litters, and also between litters. Acid secretion in the stomach occurred in some pigs from I d of age, but in others significant quantities of $\mathrm{HCl}$ were not produced before $24 \mathrm{~d}$ of age. In some of the pigs born and reared in a 'conventional' environment $\mathrm{HCl}$ secretion was detected early in life, and then ceased for a period.

Histological examinations of the gastric mucosa of fistulated pigs which were killed before $\mathrm{HCl}$ had been detected in their stomach contents revealed numerous parietal cells, and confirmed previous findings that parietal cells are present from birth (Greenwood, 1884-5; Bensley, 1903; Sloss, 1954; Noakes, 1971). The results of recent studies by Forte, Forte \& Machen (1972) have indicated, moreover, that the gastric mucosa of pigs up to $5 \mathrm{~d}$ old is readily stimulated by histamine to produce acid in vitro. There is, therefore, morphological and physiological evidence for the existence of acid-secretory cells in the gastric mucosa of the very young pig. The failure by some pigs to secrete significant quantities of acid may then be tentatively ascribed partly or completely to the following: the absence or inadequate development of secretory stimulatory mechanisms; the partial or complete inhibition of acid secretion by organic acids; or alteration to the permeability of the mucosa by fermentation products or micro-organisms.

Acid secretion results from the interplay of nervous (vagal) and hormonal (gastrin) activities, and there is little doubt that gastrin occurs in the adult pig, as the antral mucosa is a potent source of this hormone (Gregory, 1967). The recent findings of Cranwell \& Titchen (1974) indicate that secretory activity in the stomach in the newborn piglet also results from stimulation of the gastrin mechanism. However, isolation and characterization studies are required before a full assessment can be made of this aspect of the secretory mechanism. Similarly, further information is necessary before variation in the functional development of the vagi in relation to acid secretion can be assessed.

The present results, however, did suggest that acid secretion was absent or much reduced when there was marked fermentative activity in the stomach, with accumulation of lactic acid and a decrease in intragastric $\mathrm{pH}$. Under these conditions there may have been inhibition of gastrin release, with a consequent partial to total absence of acid secretion.

This hypothesis finds support in the report by Andersson (1967), who considers that intragastric inhibition of acid secretion is mediated by hydrogen ion concentration 
and not specifically $\mathrm{HCl}$. Thus the presence of ionized organic acids in the antrum at a sufficiently low $\mathrm{pH}$ could inhibit acid secretion. Further, as acid-secretory response to the ingestion of milk is minimal in the suckling pig (Kvasnitskii, I95I) and since Andersson \& Nilsson (1969) have found in the dog that acid-secretory responses to threshold doses of gastrin were significantly inhibited at $\mathrm{pH}_{3-4}$, inhibition probably occurred because $\mathrm{pH}$ values of the same order were commonly found in the stomach of pigs reared conventionally.

In the pigs in which lactic acid was produced in significant quantities in the stomach there was considerable variation in the age at which $\mathrm{HCl}$ could be detected consistently, and in most instances this was accompanied by a sharp decrease in the concentration of lactic acid. The ingestion of creep feed, a more potent stimulus for acid secretion than milk (Starovoitov, I957), probably contributed to this changing situation. It has been reported by Kvasnitskii (195I) in the pig, and Drasar, Shiner \& McLeod (1969) in man, that $\mathrm{HCl}$ has an inhibitory effect on the stomach flora. Further evidence of this effect in older animals comes from Smith (1965), who found that, compared with the contents from the body of the stomach, the contents from the gastric antrum had a lower $\mathrm{pH}$ and a lower count of lactobacilli; also Danilenko, Starovoitov \& Kaplan (1968) found that the lactic acid concentration was lower in the fundic region than in the cardia. In the pigs which were born and reared in an isolated 'clean' environment the initial bacterial load in the stomach may have been low enough to allow the $\mathrm{HCl}$ produced to inhibit fermentative activity. There appears, therefore, to be a relationship between environment at birth, acid secretion and lactic acid production in the stomach.

The production of lactic acid by the stomach flora may represent only a small loss of dietary energy, provided it is available to the pig. For example, if half the lactose of sow's milk is fermented to lactic acid only $3^{-4} \%$ of the energy supplied as lactose would be lost. However, since both the $\mathrm{D}(-)$ and $\mathrm{L}(+)$-isomers are produced in more or less equal amounts, and they are both absorbed from the gastrointestinal tract at the same rate (Whittakers, Cranwell \& Johnston, 1974; Christie \& Cranwell, 1976), a more serious loss in energy could result because $\mathrm{D}(-)$-lactic acid is not utilized as readily as $\mathrm{L}(+)$-lactic acid in mammalian tissues (Brin, 1965). A further possible loss of energy is that lactic acid is utilized by the intestinal flora to form VFA (Michel, 1962; Friend et al. 1963). However, from the results of indirect calorimetric experiments carried out during the period immediately after a meal (Charlet-Lery, 1964), it would seem that energy supplied as lactic acid or maize starch is utilized with similar efficiency. Møllgaard (1946) and Hansen \& Møllgaard (1947) found in older pigs that sour skim milk, containing a large amount of lactic acid, had a beneficial effect on growth, although their results were not confirmed by Braude (quoted by Charlet-Lery, 1964).

The authors thank Miss Angela Tysoe and Mr Keith Lilley for their invaluable technical assistance; also Dr D. W. Holme and his staff of the Pig Section, Unilever Research Laboratory, Colworth House, Sharnbrook, Bedford, for their co-operation, interest and encouragement. 


\section{REFERENCES}

Ackman, R. G. \& Sipos, J. C. (1964). F. Chromat. 16, 298.

Andersson, S. (เ967). In Handbook of Physiology. Section 6: Alimentary Canal, vol. 2, p. 866 [C. F. Code, editor]. Washington, DC: American Physiological Society.

Andersson, S. \& Nilsson, G. (1969). Acta physiol. scand. 76, 182.

Barker, S. B. \& Summerson, W. H. (1941). J. biol. Chem. r38, 535.

Bensley, R. R. (1903). Am. F. Anat. 2, 105.

Brin, M. (1965). Ann. N.Y. Acad. Sci. I19, 942.

Catron, D. V., Baker, R. O. \& Hartman, P. A. (1957). Proc. Res. Conf. Am. Meat Inst. Fdn 9, 23.

Charlet-Lery, G. (1964). Publs Eur. Ass. Anim. Prod. no. I I, p. 279.

Christie, A. \& Cranwell, P. D. (1976). Proc. Nutr. Soc. 35, 27 A.

Cranwell, P. D., Noakes, D. E. \& Hill, K. J. (I968). Proc. Nutr. Soc. 27, 26A.

Cranwell, P. D. \& Titchen, D. A. (1974). Res. vet. Sci. 16, 105.

Cunningham, H. M. \& Brisson, G. J. (1957). F. Anim. Sci. 16, 568.

Danilenko, I. A., Starovoitov, A. M. \& Kaplan, V. A. (1968). Chem. Abstr. 68, 36 Io.

Drasar, B. S., Shiner, M. \& McLeod, G. M. (I969). Gastroenterology 56, 7 1.

Erwin, E. S., Marco, G. J. \& Emery, E. M. (196r). F. Dairy Sci. 44, 1768.

Forte, G. M., Forte, J. G. \& Machen, T. E. (1972). F. Physiol., Lond. 226, $31 P$.

Friend, D. W., Cunningham, H. M. \& Nicholson, J. W. G. (1963). Can. F. Anim. Sci, 43, 174.

Greenwood, M. (1884-5). F. Physiol., Lond. 5, 195.

Gregory, R. A. (1967). In Handbook of Physiology. Section 6: Alimentary Canal, vol. 2, p. 830 [C. F. Code, editor]. Washington, DC: American Physiological Society.

Hansen, I. G. \& Møllgaard, H. (I 947). Acta physiol. scand. 14, 158.

Hartman, P. A., Hays, V. W., Baker, R. O., Neagle, L. H. \& Catron, D. V. (I96r). F. Anim. Sci. 20, II 4.

Hohorst, H. J. (1965). In Methods of Enzymatic Analysis, p. 266 [H. U. Bergmeyer, editor]. New York and London: Academic Press.

James, A. H. (1957). Monogr. Physiol. Soc., Lond. no. 4, p. 35.

Kvasnitskii, A. V. (I95 I). Voprosȳ Fisiologii Pishchevarenija u svinei. Moscow: Sel'Khozgiz.

Kvasnitskii, A. V. \& Bakeeva, E. N. (1943). Vet. Bull., Weybridge 13, 222 Abstr.

Maner, J. H., Pond, W. G., Loosli, J. K. \& Lowry, R. S. (1962). F. Anim. Sci. $21,49$.

Michel, M. C. (1962). Amino Acides 5, I 57.

Mollgaard, M. (1946). Biochem. F. 40, 589.

Noakes, D. E. ( $197 \mathrm{r}$ ). Gastric function in the young pig. PhD Thesis, University of London.

Noakes, D. E., Cranwell, P. D. \& Hill, K. J. (1968). Proc. Nutr. Soc. 27, 2 A.

Perrin, D. R. (1955). Y. Dairy Res. 22, 103.

Sloss, M. W. (1954). Am. F. vet. Res. 15, 578.

Smith, H. W. (1965). F. Path. Bact. 89, 95.

Smith, H. W. \& Jones, J. E. T. (I963). F. Path. Bact. 86, 387.

Snedecor, G. W. \& Cochran, W. G. (1967). Statistical Methods, 6th ed., p. 100. Ames, Iowa: Iowa State University Press.

Starovoitov, A. M. (1957). Nutr. Abstr. Rev. 27, 582 Abstr.

Walker, D. M. (1959). \%. agric. Sci., Camb. 52, 352 .

Whittakers, A. A., Cranwell, P. D. \& Johnson, G. W. (1974). Proc. Aust. Soc. Anim. Prod. Io, 394. 